\title{
There are ways and then there are ways: conducting research in social settings in Japan \\ Kaye Broadbent Introduction
}

From 1988 to 1990 I spent two years conducting interviews and researching in Japan. During these years I narrowed my research focus to women working part-time in supermarkets. When I returned to Japan in August $1991 \mathrm{I}$ had enrolled in a PhD programme, and the following 18 months of fieldwork and research contributed towards this. I decided I wanted to work in a supermarket and interview workers and management. When conducting research in 1988-1990 I had met senior union officials from the three major supermarket chains; as there wasn't much difference between the three, my selection was based on a convenient neighbourhood location.

I negotiated six weeks' full-time work (as a casual) in the supermarket, and started in October 1991. My job continued until early 1993. Despite the pressures of work on the supermarket shop-floor, my co-workers were extremely generous with their time, with many conversations conducted while restocking the shelves. Getting access to management and their interaction with workers was always difficult, but social occasions provided the opportunities needed. The first was a farewell for a long-serving part-time worker and the second a two-day (compulsory) company ski trip/visit to a hot springs. Note-taking (I didn't use a tape recorder) during social situations may be familiar to many - doing it in a second language presented all sorts of challenges. Interestingly, after a couple of drinks I thought my language skills were better!

\section{So how did it all start?}

My contact with union leaders and members began when, as a university student in the early 1980s, I was employed as a casual at the Newcastle (Australia) workers' club. At this time I also unconsciously adopted participant observation as a research technique when I heard many stories of strikes and struggles in large mines and railway workshops, plus the experiences of workers in smaller manufacturers when workers at Broken Hill Propriety (BHP - then one of the town's largest employers) went on strike. Sometimes the wives told their stories, too. When I went to Japan for my first research trip in 1988 to 'learn' about Japan's union movement, I learnt two valuable lessons - one, a social situation can be just as productive (or more) than the original 'research' situation, and second, small group social gatherings can allow the interviewees to take control of a situation, providing discussions and information hitherto not considered by the researcher. My first experience of learning from a social setting occurred in late 1989 when I travelled with my then supervisor from Tokyo to Hiroshima to meet a leader of a major Japanese union. This union was one of a very small minority which had succeeded in building a strong, activist union despite management's repeated union-busting attempts. It was a valuable experience and an opportunity to gain significant insight into past struggles between Japanese capital and labour, and the extent capital would go to prevent workers forming unions. My supervisor, the union leader and I were all staying overnight in a Japanese-style inn, where we 
dined together and then spent the next day on a fishing boat. My supervisor was keeping up to date with the union's progress and I was there to hear first hand of a well-documented struggle. The union leader had many stories to tell and was a seasoned drinker. I'd heard it was polite to drink when it was offered. Many hours of politeness later resulted in my being barely able to stand. I subsequently discovered that my supervisor had turned his glass upside down, indicating he wasn't drinking any more - an option he'd neglected to tell me about. At the end of the evening I managed to get to my feet and make it to my room, but was very unwell for the rest of the night, to put it politely. I managed to survive the next day's activities and the fishing trip. When I discovered that the union official was also feeling 'under the weather' I didn't feel quite so foolish, but needless to say I have almost no memory of what was discussed that evening and my notes were very little help at all. This was an important lesson, and based on this experience I moderated my alcohol intake in social settings with a fieldwork aspect. The following discussion focuses on two examples of conducting fieldwork in a social setting where the interviewees for my research (part-time and casual workers) were able to 'take charge' of the situation. As a 'passive' participant observer I gained information and insights which I may not have gained in the workplace setting.

\section{In the beginning...}

From 1988 to 1990 I conducted many interviews with union leaders, officials and members in Japan. I also attended many rallies, protests and pickets as a way of 'learning' about Japan's industrial relations context and determining the focus of my research for a $\mathrm{PhD}$, and I gave talks to unions keen to understand industrial relations in Australia. I was very fortunate, and grateful for the generosity of everyone concerned, but a vague feeling of unease remained. I hadn't decided the area of research I was interested in pursuing, nor had I decided on the research methodology I would use. I was interested in the experiences of women workers, but had spent a lot of time with male union leaders and officials from male-dominated unions. I wanted to know 'where are the women workers?', which is not an original question (Kessler-Harris, 1975). Six months into my fellowship, in June 1989, I had the good fortune to meet a very dynamic woman professor from a different university to the one I was attached to. When I talked to her about my vague ideas for a project and told her who I had met and how I was attending a range of union conferences, her response was that I was conducting research like 'a middle-aged man'. She suggested that if I wanted to meet Japanese women workers I should just go and talk to them about their work. I loved the idea in principle, but thought the practicalities would limit the efficacy for data-gathering. Apart from the difficulties of cornering someone for a chat when they're busy, and having worked 'on the other side' in a supermarket it is always extremely busy, I wondered how people would respond to a 'foreigner' with less than perfect Japanese asking about their work. I decided that I wanted to focus on women workers, and selected part-time work in supermarkets, an industry and employment status predominantly occupied by women. I spent the remaining 18 months of my fellowship, until March 1990, interviewing supermarket union leaders, officials and part-time workers from Japan's (then) three largest supermarket chains. I had met senior union leaders from these chains in 1988, so when I returned in 1991 I selected the 
Daiichi company (pseudonym) because it was the largest chain and also it had a store in my local neighbourhood - I could walk to work and not have to be 'stuffed' into overcrowded subway trains! After sitting an aptitude test and an 'interview', I started at Daiichi's Hachiban store in October 1991.

Unsure how long I would be permitted to conduct fieldwork and thinking I might be perceived as an inconvenience, I requested a six-week 'contract'. At my 'interview' I was hired for six weeks' full-time work (as a casual) in the 'hard' section (stationery, toys, novelty, haberdashery, Manchester and non-electrical household goods). By year-end, when the store was approaching the busy season, I was approached and asked to stay on until the early new year. I was ecstatic, as six weeks had proved to be too short a time to conduct fieldwork. I needed not only to learn the language of 'retail' but to learn it in Japanese. From the beginning I advised my co-workers that I was conducting fieldwork for further study and was focusing on the nature of part-time work in Japan. My presence became a source of interest, and led to me gaining many more willing interviewees. Many co-workers from other departments were curious as to why a native English speaker would work in a supermarket for about AU\$6 per hour when they could earn AU\$100 per hour teaching English.

My 'six-week stint' as a full-time casual ended in August 1992, nearly ten months after I'd started, but I continued to work one day a week until early 1993. After having my 'contract' renewed until the new year, the store left it to me to decide how long I wanted to stay - it indicated it was quite happy for me to continue indefinitely. I estimated I needed several more months, and the store was happy to comply. Despite my limited language abilities I was useful as an employee, as the Japanese economy was suffering serious labour shortages, and while 'retail' was not considered a $3 \mathrm{~K}$ job (translated to be dangerous, dirty and hard), it was low paying and thus unappealing to many workers. For the company, any worker was better than none.

My experience as a casual worker differed from my part-time coworkers because I worked from $10 \mathrm{am}$ to $4 \mathrm{pm}$, five days a week, which was at least an hour less per day than most part-time workers. I worked no Saturdays and very few Sundays, which again differed from most part-time workers. I reasoned that I needed a few hours each day to write up fieldwork notes, conduct research and begin writing my dissertation. Unlike other casuals or part-time workers, I was able to reduce my workload to one day a week - a decision reached through a combination of exhaustion and needing to speed up the process of completing the fieldwork component of interviews and surveys. Despite the pressures of work on the supermarket shop-floor, my co-workers (mostly women) were extremely generous with their time, with many conversations conducted while restocking the shelves, during lunch hours, after work and on outings arranged on common days off.

\section{Minamoto san's so-betsukai (farewell party)}

I had been at Daiichi about three months when Minamoto san (pseudonym) turned 60 years old and had to retire as a part-time worker. Her farewell party presented my first real opportunity to listen in and observe conversations between the 'hard' section manager and a small group of part-time workers. I spent most of my time at Daiichi working 
in the 'hard' section, with short rotations through all the 'hard' departments except for Manchester and household goods. I also had a short rotation in the women's clothing department ('soft' section) to get to know a different group of workers. Regular day-trips with part-time workers and an 'overnight' ski trip meant I got to know a large number of part-time workers in other sections as well. At the time of my fieldwork I was 30 years old, at least eight years (sometimes as much as 12 years) older than many of the young female full-time staff. The combination of my research focus and casual status meant I spent more time in the company of, and socialising with, my part-time co-workers aged 50-plus than I did with young full-time workers.

Minamoto san (part-time) had been with the store 17 years. Even though the company demanded she retire as a part-time worker at 60 , it rehired former part-time workers on a casual basis. Minamoto san started again as a casual and also requested to work only four hours a day, instead of eight hours as a part-time worker. Her request was refused and it seems the section manager, Hashimoto san, refused to give her a satisfactory reason. When I asked our department manager why Minamoto san's request had been refused, he simply mumbled something about company policy and indicated that the conversation was ended. My guess is that it was because the store wanted Minamoto san to continue to work long hours, given that it knew her husband worked full-time and she had no dependants at home (aged parents, children or grandchildren) to present a constraint or justify, in the section manager's eyes, her working shorter hours. Management also knew that it would be difficult to get someone with Minamoto san's length of experience so cheaply. The experience of Minamoto san and other parttime workers led me to formulate the argument that part-time work in Japan was constructed to benefit employers' demands and not the needs of part-time workers (Broadbent, 2003).

I had worked closely with Minamoto san in the toy section, and her appearance suggested a sour and sullen demeanour. On the contrary, she had a dry sense of humour and was easy to work with, but had been ground down by many years of low-paid work with poor conditions, unrelenting pressure to reach sales targets and the need to manage her emotions with both customers and management. She was a patient teacher whose best efforts (combined with those of others) in teaching me even the basics of the beautiful Japanese style of gift-wrapping were to no avail. About 25 of us attended Minamoto san's so-betsukai at a Japanese-style bar near the store; managers, including the toy department manager and the manager of the 'hard' section, Hashimoto san, were also there. Having managers, but especially the section manager, present seemed to offer unprecedented access opportunities for all the staff, but especially for part-time workers who were considered marginal to the store's operations - although, with casuals, they were numerically the largest section of the workforce. Japan's unions are regularly criticised for their close relationship with management (see Kawanishi, 1986), and recent surveys indicate the reluctance of union leaders to organise non-regular workers, such as part-timers and casuals (Rengo--Osaka, 2001), or to fight management to organise the growing non-regular workforce (Broadbent, 2008); this is also the case in the supermarket sector. At Daiichi a minority of part-time workers have been 'permitted' to join the union (Broadbent, 2003). That only a limited group were permitted to become union members is one reason why the national part-time union membership is estimated at only 3 per cent (Japan Institute of Labor, 2006). 
Once the dinner was finished and the speeches concluded, the various groups joined and the next hour-and-a-half became a 'conversation' between part-time workers and the managers. Hashimoto san, the section manager, was asked to justify a number of changes to staffing and working conditions. While I have no evidence of this, my guess is that many more criticisms, comments and suggestions were volunteered here than were ever heard by management through other channels. The benefit of suggestions 'offered' in this way was that Hashimoto san could ignore or accept them as he chose, and the offerer could feel uninhibited because the tacit understanding was that it was a social setting and so the atmosphere was less constrained, and the offerers had been drinking so they were not thought any less of for making critical comments.

Yoshizumi san from haberdashery was a key interviewee for me. She conversed with Hashimoto san for about 15-20 minutes, with myself and others also present. I suspect this represented more time spent with him than any part-time worker had done in a long while. The part-time workers at the Hachiban store were a little unusual, as many of them had more than the average work experience of part-time workers, with the majority having worked over ten years at the store. What I also found out later was that in 1980 Yoshizumi san and many of the other parttimers I knew had been instrumental in successfully agitating for parttime workers at Daiichi to be unionised.

\section{Shatta-renkyu- - to Kusatsu we will go!}

In late January 1992 the Hachiban store closed for two days, the longest consecutive period of time that the store was closed. It was a break in lieu of the traditional New Year holiday in Japan (1-3 January), when most businesses close but more and more retail outlets remain open, and it is at this time the store chooses to hold its company 'bonding' session. This trip provided the second opportunity to observe interactions between part-time workers, casuals and managers in a relaxed atmosphere away from the workplace. It was the first time that it occurred to me that my part-time worker friends were asking questions to assist my fieldwork process.

This year, staff from the Hachiban store were to take their shatto-renkyo- at Kusatsu, a ski resort with hot springs, approximately two hours by bus west of Tokyo. The shatto-renko- was a company-paid trip to thank staff for their efforts during the year. It was not voluntary, as almost all full-time workers had to attend and were expected to ski; for the first time part-time and casual workers were invited, but their participation was voluntary. The 20 or so part-time workers who attended were excused from skiing and were free to enjoy the hot springs. I opted for the hot springs, because of my research focus, so I spent many hours with my part-time colleagues sightseeing around the area.

The Daiichi group arrived at the resort hotel around mid-morning and, once we got our rooms and room-mates sorted out, about ten parttime workers from various departments/sections and I gathered in one of the part-timer's rooms and started a party. People had brought scotch, sake and beer. We used icicles hanging from the spouting outside the window to mix with the scotch, while debating the possible pollution levels and toxicity of using this ice! The background noise to the party was the televised announcement and commentary on the engagement of the Crown Prince and his fiancée Owada Masako. This went for eight hours - about the same time as our party. This was the era of the Princess Di phenomenon, with the emphasis on accessibility of the monarchy to 
the people. Through the young Japanese couple, Japan's powerful Imperial Household Agency was demonstrating that Japan's monarchy was also accessible.

As the party progressed various people came and went, including a few managers. After things had been in full swing for about three hours, the manager of the household goods department, Koma san joined us. I hadn't met him before, so it was a good opportunity to hear his views. Mikawa san, a casual in his department who had 15 years' experience, claimed that she had both the length of service and the job knowledge to be a manager - something many part-time workers and casuals asserted, though not quite so publicly. His response was that these were not the most important criteria, commenting that it was the content of the job you performed, your employment status and whether you made 'decisions' that were most important. As many of the part-timers I worked with knew their job and how it compared with those of full-time workers, few were persuaded by company arguments that their jobs differed from those of full-timers. In light of the fact that many of these part-time workers were solely responsible for a small department, his comments underscored the discrimination practised by companies towards part-time workers. The attitude was that part-time workers were incapable of taking on management roles because they were 'parttime', which in Japan still remains code for 'housewife'. Recently Daiichi and the other large supermarkets, spurred by the need to cut costs, have replaced full-time workers by 'promoting' part-time workers to managerial positions.

Mikawa san and the other part-time workers at the party continued to ask questions such as these, questions that I may not have considered, and provided me with evidence to support my argument that the construction of part-time work in Japan is gendered. Over the course of an eight-hour drinking party I was able to get notes on most of the conversation - not all of which was relevant for my fieldwork. I did notice that when managers were present, 'work'-related conversations dominated. The social situation provided part-time workers with the opportunity to pursue issues which weren't addressed in other forums. Many of the part-timers I knew well also asked questions they considered important to my fieldwork.

Over the course of my fieldwork I did have conversations with two managers I worked with, but generally I kept my contact with management to a minimum for two reasons: first to maintain my credibility with part-time workers, and second because I was interested in the 'voices' of part-timers. Parties and social occasions (there were a couple of others) provided opportunities to hear managers' responses to the issues affecting part-time workers, and the situation was such that they were confronted by several part-time workers who would not be satisfied with evasive responses. The discomfort of managers confronted in this way was clear, but, unlike the store manager, most responded directly and it seemed to me with candour. After all, the part-timers had more experience working in a supermarket than almost all the managers did, but by virtue of their gender, age and marital status they were confined to low-paying, low-status jobs with almost no prospects for promotion. It also benefited my research because I participated in discussions on issues I may not have considered and gained insights that I wouldn't have had access to in a workplace setting. While participant observation was only one of the methodologies I utilised, it is time-intensive and not for everyone. It suited the topic of my research and my personality, and I benefited from the experience. I made 
close friendships with many of my part-time co-workers, learning so much more about Japan, Japanese people and industrial relations in Japan than I could have from only reading, questionnaire surveys or conducting 'one-off' interviews. My research only scratched the surface of the work experiences of part-time workers in supermarkets, but the cooperation of my co-workers and the invitations to participate in their social activities mean the data I gathered were richer as a result.

\section{Acknowledgements}

This research was assisted by many people, with acknowledgement due to the staff at Daiichi supermarket's Hachiban store - in particular the part-time women I worked with, who befriended me and contributed to a rewarding research experience. 